\title{
集合行為と階層的集団形成
}

——集団カテゴリーの物象性＝象徵性をめぐって——

\section{丹辺宣 彦}

M. Olsonの集合行為論は，共通の利害を有することが集団形成を促すとい う階級論の想定に対して，有効な批判の論拠を提供してきた。他方で，その 問題構成には，集団間の階層的分化への顧慮と，集団への関与がその成員の 意識と行動に大きな影響を与えることを考慮する観点が相対的に欠けていた。 この点に着目し，本稿では，階級的・階層的集団の成員の意識にあらわれる カテゴリー形成を手がかりとし，それが集団形成と集合行為をいかに水路づ けるかという問題を論じる.

まず, Olsonの集合行為論の問題点を整理し，その議論が集団間での階級的， 階層的な利害の分化を捨象しており，また他方で集団カテゴリーの成立を前 提としていたことを示す（1節)，つぎ，集合財の階層性を確認するととも に，C. OffeによるOlson批判も，労働組合成員による「集合アイデンティテ イ」カテゴリーの創出という, 個人的合理性に対置される集団的連帯性に依 拠していたことを示す (2節)。ささらに，集団間での利害対立の分化が新たな 集合財空間の分化をもたらすことを明らかにする。その上で，属性を物象 化二象徴化することにより階層的な集団カテゴリーが形成される機制と，集 団と個人の利害の同一視によって，フロントランナーの集合行為が引き起こ される可能性を検討する (3節)。このような検討から, 集合行為論の展開に 対して, 社会学的観点からの貢献が可能であることを示したい.

キーワード：集合行為，階層，物象化

\section{Olson集合行為論のインプリケーション}

客観的利害をおなじくすることがある夕イプの行為を引き起こすか，あるいは さらに進んで，なんらかの集団や組織を生み出すかどうか，という問題は，階級 論・階層論にとどまらず，社会学全体にとって非常に大きな意味をもつ問いであ った。財の配分上の客観的位置になんらかのかたちで準拠して「即自階級」とし ての階級の存在について語ることは可能であるが，行動する主体というイメージ にふさわしい「対自階級」としての階級の実在について語ることは極めて難しく， K. Marx の階級論が抱えている最大の問題点となっていた. M. Weber 以降展開さ れた「弱い階級論」の理論枠組は，利害と階級行動との対応関係を大幅に緩和し 
たが，なお共通の利害関係が，同一の志向をもった行動を相対的に高い確率で生 じさせるとする発想に立っていたといえよう。『集合行為論（The Logic of Collective Action)』（1965）における M. Olsonの理論の意義は，階級的に共通の利 害をもった多数の個人が存在するところで, 階級行動や階級組織が発生して共通 の目的に向けて活動するはずだとする古典的な階級論以来の命題を理論的に否定 し, しかもそれを合理的な選択をおこなう個人の行為という理論枠組から説明す ることに一定程度成功した点にある。しかし, その理論枠組には, 階級的・階層 的集団形成に関与する個人が直面する社会的リアリティやその変化をとらえる観 点が欠けているという久陥も他方でみられる. 本稿では, 後者の視点から集合行為 論の枠組を問い直し，階級的・階層的集団形成が個人の意識にもたらす効果，変性 とそこで成立するカテゴリーの形式という点からその問題点を検討してみたい.

Marxが予言したような階級的行為が営まれないのは, 一つには合理的な功 利主義的行動が支配的であるからである，というのは，階級を構成する個人が 合理的に行為しようとすれば，階級志向的行為はむしろ営まれないであろう． ……『フロレタリア政府』ならば利益が得られると考えている労働者とても， ブルジョワ政府に反抗して革命を起こしてまで，その生命と財産を危険にさら すことが合理的であるとは思わないだろう……．（Olson 1965：105-6=1983: 131-2)

Olsonは，人間が組織を構成したり集合的な行為に参加するのは，その際に，協 力から生まれる共通の利益（common interests）が得られるためだと考えた。多く の組織——Olsonはとくに経済的側面をともなう組織を重視している——を特徵 づける唯一の目的は「所属構成員の利益を増進すること」だと言うのである (Olson 1965: 5=1983: 5)。この立場からすると，組織は構成メンバーの利益を 増進する限りで維持存続することになる。そしてここで理論上重要な役割を担う のが，「集合財 (collective good)」という概念である。これは，「ある集団の成員 $X_{i}$ が消費する場合に，集団の他の成員もそれを使用することを排除できないよう な財」と定義される（Olson 1965：14=1983：13）。しかし，メンバーが利用する ことができる「集合財」は，供給量が必要量を下回る傾向があり，しかも集団や 組織が大規模化すればするほどそうなる傾向があるとOlsonは言う（Olson 1965: $55=1983 ： 65)$.これは，個人への集合財からの配分量が小さくなる傾向があり， 成果を実現するためには大きな負担と労力が必要になるので，個人の利得は減少 し活動の成果は他人のものになってしまい，少数の意欲的な人間以外は活動の動 機づけを失うからである。こうして, フリーライダーが発生するのである.

以上の事態をOlsonは，つぎのような数量的表現に表わしている， $i$ 番目の個人 への分け前の比率を $F_{i}$, 費用を $C_{i}$, 集団の利得を $V_{g}$ とすると, 個人がプラスの利 得を得る $\left(V_{i}-C_{i}>0\right)$ ためには, 


$$
F_{i}\left(d V_{g} / d T\right)=d C_{i} / d T \cdots \cdots
$$

となる水準が最適となる.

個人が入手する集合財の最適量は, 集団の利得に個人が入手する集団利得 の割合をかけて，それが集合財の総費用の増加率に等しいときに満たされる. ……集団の成員数が多くなればなるほど，他の条件が等しければ， $F_{i}$ [ 個人 の分け前］は小さくなるので, 集団内の個人が多ければ多いほど, [集合財供 給の] 過少性はより重大になろう．(Olson 1965：24=1983：22-6)

個人個人が集団全体のために高価な犠牲をはらうことをためらうため, 大規模 集団ほど集団の目的にとって必要な行為や財は調達できなくなる。そして Olson は，階級も，利害関係を共有する点では大規模な集団とおなじ性質をもっていて， 目標を達成するためのコストや労力を個々のメンバーは負担しようとはしないと 考えたのである. 労働者や資本家, 自営業者の人数は膨大になるため, 階級的行 為はむしろ最も発生しにくいことになる.

ただし, 大規模な集団でも, 集合行為が発生しないわけではない. 集合行為と セットになった私的な誘引を得ることができるか，権力によって「強制」されれ ば，成員は集団的活動に参加する誘因をもつことになる，全米医師会 (American Medical Association）のような組織がメンバーの数が多いのに強力なパワーを持っ ているのは, 医療過誤にたいする弁護活動や，医学雑誌を通じた有益な情報の提 供など，有益な私的利益すなわち「選択的誘因」の提供とともに，除名された場 合には保険医の資格を失うなどのデメリットが生じるためだと言う，労働組合の ケースでは, フリーライダーやスト破りの発生を防ぐために, 強制加入方式や, ストライキ保険の導入や, リクリエーションの提供などに努力することになる. これらは，正負のサンクションや強制を導入し，集合財を副産物化することによ り, 個人のモチベーションと貢献を調達しょうとする努力をあらわしている. 革 命や社会運動, 宗教改革も, 少数の革命家やリーダー, カリスマが自己の利益の ために起こすプロジェク.トの副産物であるか，強制によって民衆を服従させたこ との結果であることになる.

このように，共通の利益があれば階級的行動が生じたり階級組織ができてくる ことを予想する古典的な階級理論の想定を明確に否定したOlsonの集合行為論の 意義は大変大きかった．しかし Olsonの図式にも問題点がないわけではない.さ まざまな批判がなされているが（Smith 1976; Oberschall 1978=1989; Roemer 1978; Fireman \& Gamson 1979=1989; Taylor 1982; Offe 1985; 宮本 1983; 長 谷川 1985; 车田 1986; 木村 1991; 森脇 2000 etc.), そこで指摘されていること は, 第 1 に, 経済的な組織をモデルとしており，宗教団体，イデオロギー団体な ど集団目標自体が個人目的と一致する集団への参加に議論が妥当しないという点, 
あるいは集団目標への貢献と成員の個人的目標とが競合するという前提に立って いる点である (Hirschman 1982=1988: 100 $)^{1)}$. 第2に, 成員の同質性を前提と しているという問題がある。この論点は成員の階層性の問題に直接かかわる。ま た第 3 に集団規模の拡大がつねに集合行為を抑止するとは限らないという問題が ある（木村 1991：174-6）. さらにM. Douglasも指摘していたように（Douglas 1986），小規模な集団がつねにメンバーの集合行為を活性化するとは限らず，集合 行為は集団がある程度の規模にならないとむしろ活性化しない場合がある. 第 4 にOlsonは成員が自身の行動の前提や帰結, 効用関数について完全な情報をもっ て行動することを想定しているが, 集団への所属はこれらの変数の值を変えてし まうという問題点がある。第 $5 に$ に, Olsonの想定した合理的主体は，個人としては 利得を最大化するよう合理的にふるまうが，他者や集団にたいしてどのようにふ るまうことが合理的か, という前提を置いていない（Taylor 1982：55).「彼のモ デルに抒いては，他者の供給する集合財の量（あるいはそれに対する予想）や， 行為者の意思決定が他者の意思決定にどのような影響を及ぼすかといった要因は まったく考慮されていないのである」(木村 1991：177).

さらにここでは第 6 の論点として次のような問題が挙げられよう: 第 1 , 第 4 , 第 5 の論点とも関連するが, 総じて, Olsonのモデルは, 所属す方集守市組織の論

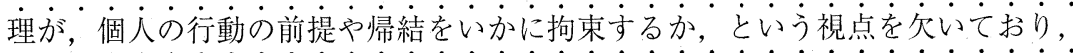

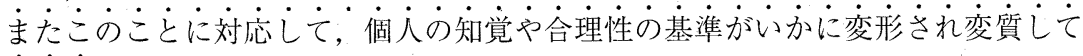
斿か，という問題構成もない2 ${ }^{2}$. 長谷川公一も述べているように, 「Olsonのモ デルでは，集団利益も個人の評価関数も所与とされているために，これらの意識 変容過程がモデルのなかにはいりえない」のである（長谷川 1985：137）. 第7に， これもいくつかの論点に関連する前提として指摘しておきたいことは, 集合財を 集合財たらしめ，また私的な財を私的な財たらしめているのが，利害関係を組織 する社会制度の特定のありかたであるということである。「ある集団の成員 $X_{i}$ が消 費する場合に，集団の他の成員もそれを使用することを排除できないような財」 という性質は，その剘のア・プリオリな性質と考えることはできない，公園や道 路は制度的に公共財でありうるが，そうしょうと欲すれば，私的に占有し，他者 の使用を排除することができる，空気や流水のように，自然の性質が私有を困難 にし集合財になることを促すことはあるにしても，それはやはり社会的に決定さ れていると言うべきである ${ }^{3)}$. とくに所有や占有にかかわる制度的決定は，この 点に大きな影響をおよぼす。

以上の点から，階級・階層論の観点へのインプリケーションを考えてみよう ${ }^{4)}$. とりあえず次のような問題点を挙げることができよう. 第 1 に, Olsonの集合行為 論では, 労組や経営者団体など階級的組織について分析されているようにみえる ものの, 階級・階層関係が利害関係の分化を通じて労使それぞれの行動におよぼ す影響の差異そのものは分析されていない. 階級的集団は単体では分析されてい るものの, ひとつの社会や集団内での階級的分化の効果は検討されていないので 


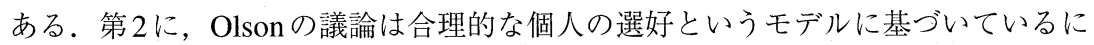
もかかわらず，業績と報酬の評価に関しては一一おそらくは，個人単位の貢献が 「認知できない」ことを理由に5 一集団への帰属や属性原理にしたがうて決ま方 ことを前提としている. ある企業やその部署・職種の従業員であったり, 女性で あること, あるいはある共同体のメンバーであることが, 自動的に賃上げや差別 撤廃の恩恵に浴するための十分条件とされているのである。もし集合財の配分が こうした意味で「平等」でなくなり，フリーライダーが生じないように，従って 個人を単位とする厳格な業績主義にしたがって集合財が配分されるのであれば， この議論は成り立たなくなる。この意味では, Olsonの議論はなんらかの共通属性 にもとづくグルーピングと, それとセットになった襄属主義的業績評価がおこな われている社会的価值を前提条件として挿入してしまっていると言えよう。第3 に, Olsonの議論はイデオロギーや宗教的観念, レイシズムなど, 一一後段で述べ る——「物象化された」階級的・階層的意識形態の役割や意義を無視していると 言えよう。これらにより，一文の得にもならない奉仕活動に私的な喜びや生き甲 斐を感じさせたり，自分の利益を増進しているという錯覚にしたがって，集合的 な行動が組織されることもあるのではないか.

上の 3 つの論点は, 公共的, 集合的な利益と私的な利益の関係が, なんらかの 制度的措置や回路によって両立可能になり, そしてそこに階級性・階層性と, そ れにともなって生じる社会意識の変性の問題が大きく関与してくることを示唆し ている，階層的集団に所属することから生じる知覚の屈折作用により，たとえば 個人が集合行為に参加することこそが，私的な利益と感じられるようになるよう な状態が成り立つ場合があるわけである，ただし，コストのかかる方策——強制 や制裁であれ，イデオロギーであれ——は，その負担をめぐって，第二順位のフ リーライダー問題を発生させてしまう。この点にOlsonの主張の頑健さがあると 言えよう。この第二順位, 第三順位のフリーライダー問題をクリアするためには, コストを要しないか, 副産物の利得がコストを相殺するような制度的回路が存在 しなくてはならないのである。

Olsonの理論は，集合財供給を妨げたりうながしたりすることを説明する一般的 な枠組を用意しているが, 社会や集団内で生じる下位の集団の階級的・階層的分 化や，分化がもたらす効果について検討は十分なされていない. 次節では, 集合 行為の発生に関わるこれらの論点を, ひとまず，階級的利害の問題に即して検討 してみることにしたい.

\section{2 集合行為と階級関係}

社会制度と集合財の成り立ちから階級・階層論との関連を論じてゆくと, Marx が問題としていた生産手段の私的所有，より広くは社会関係の物的媒介という論 点と直接につながってくる.『資本論』の本源的蓄積の分析で取り上げられた， 「囲い込み」は，共同体的管理——E. Ostromが取りあげたような—によって維 
持されていた「共有資源 (common-pool resource)」を 1. 私的に分割し，また 2. それを少数の所有者の手に集中してしまうことによって実現される（Ostrom 1990）。共同の規制は崩壊し，共有地への権利と集合財空間は消失するであろう. 代わって，土地に対する地主の経営が扔こなわれ，困窮した農民たちは，土地を 離れるか，農業労働者として働かざるをえない，他方共有資源が国有地となり， 行政の管理に委ねられると, 用益権が認められる場合でも, 不効率と錯誤と高い コストが発生し，貢献と報酬のバランスが崩れてやはり集合行為は大きく損なわ れるであろう。集合行為の発生が可能になるには，その基盤に，制度的選択が生 み出す，ある夕イプの所有・占有の（不平等な）状態と，それらがもたらす社会 関係のかたちがなくてはならないのである。さらにここから，階級対立の発生が， 共有資源をたんに消失させるのか，あるいは利害対立に対応した，新しい非対称 的な集合財空間をうく方だすのか，といったことを問うことができる。

この点に関連して，社会秩序の成立というホッブズ問題的観点から，集合財と 不平等との関係について論じたものに, M. TaylorのCommunity, Anarchy \& Liberty（1982）がある．不平等な社会のなかで守るべき富をもたず，十分な保護 を受けていない階層にとっては，公共的に負担される治安・安全という財は，プ ラスの価值をもつとは限らず，マイナスの価値をもつ財（a bad）であるかもしれ ないと Taylorは言う．社会秩序はそれを享受する層によって一方的に維持, 強制 されており，そのような非対称的な社会秩序こそが，近代国家が維持している秩 序だとみることも可能だと言うのである（Taylor 1982：47）。この論点は，マル クス主義の階級国家論の主張と実質上重なっている. M. Sahlinsの議論を援用しつ つ，Taylorは，国家による強制の出現以前に，ホッブズ的自然状態に陥ることな く社会秩序を維持していた社会集団の条件一一信念と価值の共有, 成員間の関係 が直接的で多面的であること，互酬性の存在一一「コミュニティ」と呼び，そ れが成員間の平等性を前提するとともに，フューデ，社会的評価や呪術といった 種々の社会的統制をつうじて成員間の相対的な平等性を維持していたとしている. 「コミュニティ」的秩序は小規模な社会でしか実現できないとする点で, Taylorの 観点はOlson と重なり合うが，近代社会の不平等は，社会秩序を素朴に「公共財」 と呼べないものにしているのである.

組織成員の階級的利害関係の異質性を集合的アイデンティティの問題に関連さ せて, Olsonの議論にたいしてとりわけ鋭い問題提起を抢こなったのが，C. Offe である. Offeは「利益集団 (interest group)」や「集合行為」というカテゴリーの 適用が，異質なものを等置することによって，階級的カテゴリーの意味を不明瞭 なものにしてしまうと指摘している（Offe 1985：174）。経営活動が最初から組織 されているのに対して，労働者が組合を組織する活動は「二次的組織」である. 初期状態では，労働者はばらばらの個人としてお互いに競争しあい，資本側に雇 用される，個人個人の属性や生活条件も多様で，ばらばらである。資本サイドは 生産の技術的条件を変更できるが，労働者が生活を合理的に変更する能力には限 
界がある。こうした社会的条件のもとでは，資本側が労働者を雇用しないことの コストに比べて, 労働者側が雇用されないでいることのコストは高くなる．した がって，労働者が交渉や闘争によって成功するチャンスは現存の勢力配分によっ て最初から低く押さえられているという（Offe 1985：176-82）.

ここでわれわれが主張しているのは，階級構造における集団（ここでは労 働者階級と資本家階級についてのみ考察する）の位置のちがいは，組織が獲 得する力のちがいだけでなく，組織形成の実践や，集合行為の論理の差異 一これにより資本や労働の組織は互いに対して自分の力を高めようとする ——をももたらす，ということである。『利益集団』パラダイムや，あらゆる 組織をカバーする集合行為の法則的・功利的ロジックは，こうした差異をあ いまいにしてしまう傾向がある（Offe 1985：180)

こうしたハンディキャップがあるにもかかわらず，闘争が組織されたり勢力関 係に実際に変更が生に゙ることがあるのはなぜか. Offeは, 労働者サイドが,「集合 的アイデンティティ」を定義して, 評価基準を集団の観点へと変更して設定し, 集合行為にともなう高いコストや資源の個別性を乗り越えるのだという興味深い 論点を提示している．力が欠如しているからこそ「非一個人主義的」にふるまう 理由があるのだというのである.

資本制システムでの労働者たちの組織は, 集合行為の非一功利的形態 （non-utilitarian forms）に依拠することを強いられる．この形態は, 集合的ア イデンティティの再定義に基づいており，組織が，たとえば賃上げのように， メンバーたちの個人的な功利的利害に寄与する意図しかもっていない場合で さえ，依拠することを強いられるのである，いかなる組合であれ，メンバー たちが次のようないくぶん素朴な観念をもたなくては一日たりともその機能 を果たすことはできない.すなわち集団のメンバーであること自体に価值が あり, 組織化のコストは功利的尺度で計算されるのではなく必要な自己犠牲 として受け入れられ，個々のメンバーは規律と連帯，その他の非一功利的規 範を維持することを正当なこととして要求される, ということである.（Offe 1985: 183)

異質でばらばらで力をもたない労働者たちは，そのままでは自分たちの真の 「利害」が何であるのかを「知る」ことすらできない. Olsonのモデルは, 行為主 体が「費用」と「便益」を認知しつつ合理的に行為することを想定しているが, 労働者たちにとってはこの想定自体が妥当しない（Offe 1985：203-4）.だからこ そ, 社会統合と対話, 規範と積極的行動を重視した集合行為の戦略をとらざるを えない。こうした経路によって初めて，自分たちが欲していることが何であるの 
かを知り，幻想や歪んだ観念を脱することができる—ここにまた階級理論の意 義がある—というのである（Offe 1985：204）。こうして，労働者は独自の経路 で集団形成の盆路を乗り越えようと試みる。ただし，動員できる資源を増加させ るために，規模を拡大すると，官僚制化が進展し，成員の異質性が増大するため に，最適点を越えると集合的アイデンティティが弱まるジレンマが発生し，組織 は逆に弱体化することになる（Offe 1985：185-8）.

Offeの分析は，労働者たちが集団形成をする際の問題点を，非常に鋭く提示し， 同時にOlsonの集合行為論の問題点を突いていると言えよう。集合意識や連帯の 強調は，A. Oberschallらの資源動員論とも通底する（Oberschall $1978=1989 ）$. 労働者の負担できるコスト $\mathrm{C}_{l}$ は相対的に低く，人数は多いため集合財の配分比率 は下がって個人の利得は小さくなる可能性が高い.したがって, 集合的アイデン ティティを欠くと, 労働者側の集合財供給は経営側よりはるかに先にストップし てしまいがちである.にもかかわらず，Offeの分析にもいくつかの問題点が見受 けられる.J. Elsterは, 経営側の組織化も, 企業や産業ごとに条件が異質であるた めに，労働者側と同様困難であると指摘している（Elster 1989：167）。また労働 者たちが集合的アイデンティティの探索という戦略をとるとされることについて, 第二順位のOlson問題が発生するため，そのような方策が実現することはありそ うにないことだとしている（Elster 1989: 168).

Offe の図式の問題は, 第 1 に, 労働者「個人」を準拠点とする評価基準を変え るとされた「集合的アイデンティティ」の成立は，いかにして可能であるのかを 説明していない点である。集合的アイデンティティは, 集団形成の成立に先立っ て必要な事柄として前提とされてしまっている，第 2 に，「集合的アイデンティテ イ」をもちえたとしても, 組合が労働者階級の真の「利害」を認知したり，代表 したりする保証がどこにあるのかが説明されていない点である。組織成員の利害 だけが問題になるのでないとすれば, どの範囲の労働者の, どのような項目の利 害が問題となるのか? 第3は研究の対象領域の問題であるが, 労働者階級として, あるいは資本家階級としての「集合財」のみが問題にされていて, 主体が他の主 体と階級横断的, 階層横断的に提携したり協力する際の「集合財」ないし「公共 財」の問題について語られていない点である. 市民的な組織や団体の形成を問題 とする場合には，むしろ階級的・階層的立場を異にする主体が集合行為をいかに して形成しうるか，という文脈の方が重要になる。この意味では，Offeの検討し た集団形成の事例は, 対象がやや狭く限定されていたと言えよう6).

\section{3 集合行為と「物象的カテゴリー」}

以上の議論を受けてどのように問題を展開できるであろうか？ここでは, 行為 主体の社会的知覚と, 意味付与にもちいられる集団カテゴリーの問題に着目して みたい. 集合行為の発生条件に関する Olsonの条件式, $F_{i}\left(d V_{g} / d T\right)=d C_{i} / d T$ に再度着目してみよう. 集団内外の分業が発達した状況のもとでは, この式に現 
われている諸変数のうち, 分け前比率 $F_{i} や$, 集団全体の利得 $V_{g}$ の值は個人 $i$ には 正確には㧍そらく判断できない。ここで実際に個人が知覚しており，また知覚可 能であるのは，個人の分け前を $V_{i}$ とすれば， $d V_{i} / T=d C_{i} / T$ という関係であり， その利得を最大にするにはこれで用は足りる。個人 $i$ は自分のことについてこのよ うな状況に置かれているのであるから, 他者 $j$ の条件式 $F_{j}\left(d V_{g} / d T\right)=d C_{j} / d T$

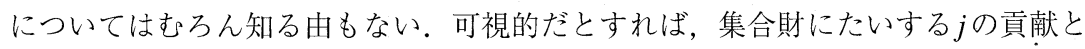
彼が享受する便益との関係であり，これも小集団や共有資源管理的状況でのみ認 知可能であろう。分業と（階級関係をふくむ）階層性をともなう集団への関与の 全体は，個人が行動の前提としているにもかかわらず，知覚することができず， この関係がまた，個人 $i, j \cdots \cdots$...がコス $C_{i}, C_{j} \cdots \cdots$...払い集合財を供給すること によって，集団に追加利得 $V_{g}$ をもたらし，それを配分比率 $F_{i}, F_{j} \cdots \cdots$ …にたがっ て分配し階層性を部分的に再生産しているのである。しかもこれは, 集合財と私 的な領域との切り分けを前提としている. 協働や参加, 分業の範囲が広くなれば なるほど，人数が大きくなればなるほど他者たちの個々の活動の意義は知覚困難 になる．

つぎに, 個人が集合行為に振り向ける資源と利得の関係を図にあらわし, 主体 間に生じる格差の拡大の効果を検討してみよう。利得曲線を $A$ で表現し, 得失が 発生するのにともない上下に動くものとしょう. 経営サイドと労働者の双方に対 して成立する集合財空間（福利厚生，衛生，安全，企業の信用など）がともにプ ラスの值をとる範囲は，得失の差が拡大すればするほど，その範囲が狭まってゆ

図 集合行為からの収益とコスト

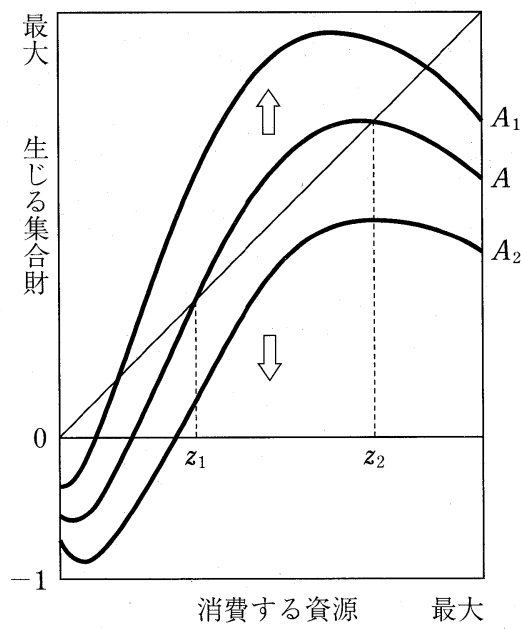

（注）Tilly $(1978=1984)$ の図をもとに作成. 
く(図の $Z_{1} Z_{2}$ 間). 先の Taylorの治安の場合のように, 最終的には, 一方にとっ てはマイナスの集合財になる状態（図の $A_{2}$ ないしさらに下方）が出現する．集合 財は，「ある集団の成員 $X_{i}$ が消費する場合に，集団の他の成員が損失を受けること （あるいはコスト負担に見合ったメリットを得られない状態）を排除できないよう な財」へと変化する，負の集合財を改善する集合行為についても，フリーライダ 一問題が発生するので, 何もなされなければ, 労働者階級（下位の階層）は経営 側と対立しつつ静かに瞄み合う。しかし階層間の関係にこのような領域が拡大す ることは，当該の関係を潜在的に危うくする．とくに「搾取」そのものやそれと 強く関連した集合財に関しては，コストと受益の関係は，知りえないだけでなく， 知られてはならない関係でもある. Olsonの理論的変数は，たしかに，現実の社会 関係とそこから発生する成果の配分というもっとも重要な関連を半ばとらえてい た.しかし，現実の個人の知覚を範型とすることによって，個々の集団成員の利 得と分配の非対称性や，集団間の対立という連関は理論から漏れ落ちてしまって いる7).

ここで，集合財供給への貢献と分配の規範に関連する，集団カテゴリーの物象 化二象徵化とその効果—とくに属性をめぐる集合的アイデンティティの形成 —について検討することが必要になる。フリーライダーの発生に関する Olson の議論では, 集合財にたいする貢献 $C_{i}$ とそこからの利得 $V_{i}$ が個々人の業績に応じ て評価されるものではなく，勤続年数や性や株主であることなど，有資格者の集 団的属性によって決まるものと前提されていたことに再度注目してみよう。もし 賃金の上昇分が，組合への所属や勤続年数で決まるのではなく，賃上げ闘争への 貢献度を個人ごとに厳密に査定して配分できるのであれば，フリーライダーは発 生しえなくなる．個人ごとに業績を査定することが不可能であるか，あるいは何 らかの理由で望ましくないという理由から，賃上げの一斉適用が制度化され，運 動の成果という集合財空間とフリーライダー問題が発生しているのである。どち らの理由によるにしろ, 貢献度と利得との関係は, その集団成員のなんらかの下 位カテゴリーとしての「属性」(性, 学歷, 勤続年数など) を引証するかたちで確 定され，またそうしたものと見なされる（属性 $X_{i}$ が貢献と報酬の算定根拠とされ， $X_{i}=V_{i}=C_{i}$ という擬似「等式」が成立する). 認知し評価する主体の主観的価值基 準と意思疎通が，そうした事実のむすびつきを探索し，つくりあげるのである。 このとき，そうした諸属性は，一方で，あるカテゴリーの集団の成員に集合財の 価値を発生させると同時に, 個人的達成を軽視させる平準化作用をも扔よほして いることになる。そしてこの属性は, 個人の業績の前提となる現実の社会関係を 捨象しながら，その主体カテゴリーにそれ自体としてそなわる「能力」や「生産 性」として読み込まれ，またそのような能力を確証・正当化する指標として機能 するのである，そのような理解は，過去の実績や統計にもとづくそれなりの妥当 性があるかもしれないが, 個人を取り巻く具体的な関係を捨象し, 縮約したとこ ろで成り立つ. 女性労働力にたいして，「統計的差別」によって处遇の格差づけを 
おこなう雇用慣行はこうした物象的な知覚の一例となろう。階級関係は，このよ うにして，カテゴリー的差別に基づく多様な階層性へと細分化されつつ接続され う。.

このような, 複雑で理解不能な, 同時に強い価値を掞びた社会関係（ないしこ れを構成する項）をなにか別の自然的事物——この場合は属性——によって表現 することによって，関係の間主観的な擬似理解を達成する機制は，Marxの「価値 形態」や物神崇扯の分析が対象とした関係，あるいはÉ. Durkheimの分類体系の口 ジック, Douglasの象徵体系の論理と基本的に相似している（社会関係 $X=$ 自然事 象 $N$ ）。このような等置のロジックに基づいて形成される集団カテゴリーをここで は仮に「物象的二象徵的集団カテゴリー」ないし略して「物象的カテゴリー」と 呼んでおく ${ }^{8)}$.ささまざまな属性をもつ多様な集団や個人をこのようなカテゴリー に基づいて評価し識別することによって，コミュニケーションが可能になり，財 やサービスの流れが淀みなく進行してゆくことができる．社会関係を迁回し表現 するこのような評価の等式は，他方で，反省作用を欠くと，主体の能力と成果と を短絡して結びっける回路となり，しばしば性差や人種，学歷に関する偏見やイ デオロギーの苗床となってしまうことも否定できない.

ところで, こうした知覚と「物象的カテゴリー」によって成り立つ属性集団は フリーライダー問題を克服できない潜在的集団につねにとどまるのだろうか. む しろ，性やエスニシティや出身地域，信仰宗教などの属性をもつ集団こそが，現 代社会のもっとも活発な磁場となり運動体を生み出していることをどのようにし て説明できるのだろうか. じつは，上の物象的なカテゴリー化 $(X=N)$ に関与す ることによって，多様な性質を備えた諸個人のうちから，一定の「属性」のみが 選び出されてその「本質」とみなされ，それを根拠にグループの一員とされると いう奇跡が，つかの間ながら意識のなかで達成されると考えられる．間主観的な 一致を志向し，認識と価值評価の混交した主体のイメージが創出される。この属 性が集団の規範として指し示す行為の道筋を主体がたどるかぎり，集団への貢献 は，すべての成員にとっての福利増進であり，プラスの評価の対象になる，外集 団の成員との差は逆に強調され，彼らとの利害の同質性は覆い隠されてしまう.

さきのOffeの場合は, 自分たちの利害を正しく認識することができない異質で ばらばらの労働者たちが，その湓路を突破するために，集合的アイデンティティ を対話によって創出し，合理性の基準を変更することを要請されていた。こうし た状況が一挙に実現することを「ありそうにないこと」たと批判したElster も， 他方でさまざまな社会的規範やその混合状態が集合行為を引き起こす条件を検討 している，それによると，「全員の協力が全員の違背よりも良い結果をもたらす場 合に，その限りで個人は [無条件に］協力すべきだ」と考える「俗流カント主義」 と呼ばれる立場に立つ者が触媒になり，「公平規範（norm of fairness）」を重視す る者がそれに追従して協力者の数を最初に増やすとされる (Elster 1989：192, 205). ここで興味深いのは，最初の一歩を踏み出す「俗流カント主義者」が，ある種の 
「哠術的思考 (magical thinking)」に陥ることによって第一歩を踏み出すとされる 点である，彼は，全員が協力する状況と誰も協力しない状況を想定し，どちらの 状態が実現するかは自分にかかっていると思いこむのである，自分が協力に踏み 切れば，他人も協力するだろうと考えるわけである，しかし，Elsterはこれを，因 果関係と診断とを混同することに等しく，兆候に働きかけることによって原因を 変えることができるとする信念だ言う（Elster 1989：196）。たしかにこの関係 には，E. Leachが指摘していた呪術的行為の図式と極めて近い内容をみてとれる （Leach 1976）。実際に他者の協調行動をみてから協力をはじめる「公平規範」を もつ者にしても, その結果や効用を顧慮して行動するわけではない点では「非合 理」であることに変わりはない. 条件的協調から集合行為が発生する発端に, 呪 術的, 物象的思考を置かざるをえない点で, Elsterの見解は, Offeのそれに比べて とくに合理的だとは言えない。

Offeが労働者としての集合的アイデンティティへの転換を打ち出し, Elsterが呪 術的思考を持ち出すのは, さきの議論からすれば, むしろ当然のことになる.物 象的な集団的属性を象徵化し，かつ相対的に高い価值を負荷することで，諸個人 の多様性は捨象され, 個人 (の利害) と階級的集団 (の利害) の錯視的な同一視 —これも一種の集合財空間であろう一一゙意図的にコストをかけることなく可 能になる ${ }^{9)}$. 自分は労働者であり, 仲間のために行動することが自分のためでも あるのだ，と信じることが一時的に可能になるわけだ。このように意味付与され るため, フロントランナーはより容易に行為に踏み込むことができ，階級的格差 が分化させていた集合財空間はここではじめて固有の集合行為を活性化させる. このように考えることにより，議論が妥当する範囲も広がる．自然的な「属性」 に焦点を当てることにより，階級という文脈を離れ，属性的な階層差に関わる集 団形成にもこの連関を拡張適用することができるようになるからである．先の場 合と同様に，自分は女性であり，女性全体のために行動しているのだ，と考える こともこの物象的＝象徴的な意味付与によって可能になる.

ところで，先覚者の集合財供給に対しては，おなじく利害の同一視から社会的 評価といくらかの物質的支援が寄せられるため, 集合財を供給することの得失は 実際にプラスに傾くもちろん，錯視的な利害の同一視に基づいて集合行為に参 加する者の数が増えるにつれ，こうした評価や支援は頭打ちとなり，供給した集 合財はフリーライダーに消費されてしまうことが明らかになる。このことは，当 初の幻想的な利害の同一視を掘り崩すので, 動員はどこかで限界に達する。参加 する層，支援する層は通常潜在的集団の一部に限られ，フリーライダーとのあい だに分化を発生させつつ, ある種のバランスに達するであろう. 物象的なカテゴ リーに基づく間主観性は, 先覚者による初発の集合行為を可能にするが, 行為が 実際に進行するにつれて利害の分裂が可視化しその虚偽性を明らかにするのであ る. 表象上の関係である限りで, 属性集団としての一体性という集合財の価値は, 多くの関係者にとって正の值をとるが, 集合行為が現実のものとなると, 值が負 
の方向へ振れはじめるのだと言ってもよい．このような見方をすることによって， 全員がすべて参加するのでもなく, 全員がフリーライダーになるのでもない現実 の集合行為の様相をとらえることができる ${ }^{10)}$. Olson問題は，この一連のプロセス の後半の局面を個々の主体の側からとらえていたにすぎないとも言えよう.

\section{4 むすび}

Olsonの集合行為論は，利害を同じくするものが集団を形成し，その集団が集団 利益のために行動するという，階級的・階層的集団形成の自明視された仮定に根 本的な疑問を投げかけた。しかし，本稿で検討したように，その枠組は，(1). 集 団間に存在する階層的，分業的関連を捨象した個人主義的意思決定のモデルに基 づいて抢り，とくに所有・占有関係にみられる階級的関係や集合財の競合性の問 題, あるいはイデオロギーや宗教的信念などの社会的諸条件・諸要因については, 経済的な，あるいは可視的なコストと便益といった変数に変換される限りでしか 取り込んでいない，この意味で, 個人の行為を外部から拘束する集団や社会の要 請そのものを十分に説明することはできない.にもかかわらず他方で, (2). 業績 評価に関する物象的なカテゴリー化と集団帰属に暗黙のうちに立脚しており，こ の前提をはずすと主張が成り立たない，という問題が明らかになった。

この問題と, これを階級関係の面から検討したOffeの問題提起を受けて, 本稿 では，集団間での利害関係の分化に加え，集団に関与する行為主体の意識にあら われる分業的連関の理解不能性と, 行為の際意味付与に用いられる集団カテゴリ 一の形式に着目した。階級的・階層的集団の成員としてのメルクマールを, 自然 的事物や属性と等置しそこに価值を負荷することにより, 個人が, 集団への貢献 を自己の利害と両立するものとみなすことが一時的に可能になり, 格差が生み出 し分化させていた潜在的な集合財空間をじっさいの集合行為へと水路づけること が可能になる。この意味で, 階級的・階層的に対立する利害やその共有だけが集 合行為を生み出すのではなく, 物象的=象徵的なカテゴリー形成とこれに基づく 意味連関が相作用して，はじめて集合行為が活性化することが示された。また 「属性」に価值を負荷する物象的カテゴリーの適用は，階級関係だけでなく，さま ざまな属性に準拠する諸集団への関与についても適用できることが示唆された. 集合行為の展開をめぐって生じる利害関係と意味付与との相互作用, 階級関係と 属性をめぐる諸集団の形成との関連, 階層横断的で社会全体にかかわる集合行為 の可能性, そもそもいかにして物象的カテゴリーに強い洒值が負荷されるのか, といった諸点についてはなお論じ残しているが, これらについては別稿を期した い.いずれにせよ，本稿で問題とした物象的カテゴリーの形成は，集団へ関与す ることにより, 個人が分業的連関とその理解不能性に直面し, その際に集団的属 性を物象的に象徵化することを半ば強いられつつ選択し, 既存の価值基準と意味 連関を組み換えてゆかざるをえないことを示している。 
[注]

1）集合財が競合性をもたない「純粋公共財」である場合（法律の制定をもとめる社会運動など） は，個人の「分け前」という前提も存在せず，Olsonのモデルは妥当しない（Taylor 1982: 40; 木村 1991：177-8）とする考え方は，この問題と関連している.

2）もちろん，Olsonモデルの主体は，名声や尊敬や友情などの「社会的誘因 (social incentives)」 に反応する.しかしそれらは「個別的・非集合的財」であり，「選択的誘因」としてみること が可能であるから，個人的意思決定モデルの枠内で取り扱うことができるとされる（Olson 1965：60-1=1983：71）。このような前提はその限りでは正当だが，視点を変えるとそれ自体 問題をはらんでいる：行為の社会的文脈にかかわり，前提をなす社会的誘引の内容は，集団や 組織の水準によって与えられ，所与の個人的合理性とつ权に両立可能なのではない.

3）より正確に言えば，財の自然的性質が問題にならないのではなく，その社会的関連こそが問 題になるのである.

4）本稿では，生産手段や労働能力の所有／非所有にもとづき，異なる市場能力を有する種差的 な集群を「階級」と呼んでおく、「階層」は，社会的資源の不平等な分配によって生じる集群 一一階級に対して上位の一般概念一七して考えておく.

5）したがって，業績評価に関しては，「完全情報」状態は想定されていない.

6）ただし，Offeの主張を市民的な運動の場に応用してみることはできる．雑多な階層が集う市 民的な運動，社会運動の場でも，経済的に余裕のない社会層は運動参加のコストを負担できず， 集合行為への参加に躊躇することになる．もちろん，社会運動の場合には，運動外部の資源動 員の意味も非常に重要になるだろう，社会運動に扔ける集団の範囲と集合財との関係について は， E. Amenta \& M. P. Young（1999）を参照のこと.

7）こうした問題は，C. Tillyのような明敏な論者の集合行為のとらえかたにも共通してみられ る. 彼の提示した集合行為の動員モデルでも，協働による集合財の発生と，その非対称な分配 という問題はほとんど取り扱われていない（Tilly $1978=1984 ）$.

8）「物象的＝象徵的カテゴリー」は了解不能な社会関係を自然事象になぞらえ表現する点で, たんなる記号的関係とは異なる，社会関係 $X=$ 自然事象 $N$ という等置は，異質な項をアナロジ 一により人為的に等置した擬似等式であり, 厳密な数量的等式や論理式ではない。この関係で はまた，認知上の等置と，評価上の等置がしばしば混交してしまっている．しかし便宜上，ま たMarxらの例に倣い，あえてこのように表記しておく。この点についてはGottdiener（1985） および丹辺 (2001) を参照のこと.

9） A. O. Hirschmanも公共的活動への過剰関与が，ユートピア的幻想によって可能であるとし， 類似のみかたをしている（Hirschman 1982=1988: 108-19).

10）集合行為論を社会心理学的アプローチで補うべきだとする Oberschall らや，B. Fireman \& W. A. Gamsonら資源動員論者の主張は，社会的知覚の物象性のメカニズムを考慮に入れるべきだ と言い直した方が妥当性が高まる。この点に関連して興味深いのが，『集合行為論』にたいす る宮本光晴の批判である，宮本は，個人の合理的選択，意思決定にのみ立脚するOlsonのモデ ルにたいして，「集合的合意」ないし「集合的意識」の意義を強調する。そして，潜在レ心゙ル の集合的合意が象徵作用によって顕在化され動員される組織的諸手段を正当化する機能をはた すという（宮本 1983：159）.

\section{[文献]}

Amenta, E. \& M. P. Young, 1999, "Making an Impact: Conceptual and Methodological Implications of the Collective Goods Criterion," M. Giugni, D. McAdam, C. Tilly eds., How Social Movements Matter, Minneapolis: The University of Minnesota Press, 22-41.

Douglas, M., 1986, How Institutions Think, New York: Syracuse University Press. 
Elster, J., 1989, The Cement of Society: A Study of Social Order, Cambridge: Cambridge University Press.

Fireman, B. \& W. A. Gamson, 1979, "Utilitarian Logic in the Resource Mobilization Perspective," M. N.

Zald \& J. D. McCarthy eds., The Dynamics of Soclal Movements, Cambridge, Mass.: Winthrop Publishers, 8-44. (=1989, 牟田和恵訳「功利主義理論の再検討」塩原勉編『資源動員と組織 戦略』新曜社, 93-143.)

Gottdiener, M., 1985, "Hegemony and Mass Culture: A Semiotic Approach," American Journal of Sociology, 90(5): 979-1001.

長谷川公一, 1985, 「社会運動の政治社会学」『思想』737: 126-57.

Hirschman, A. O., 1982, Shifting Involvements: Private Interest and Public Action, Princeton, N. J.:

Princeton University Press. (=1988, 佐々木毅 - 杉田敦訳『失望と参画の現象学』法政大学出 版局. )

木村邦博, 1991,「オルソン問題」盛山和夫・海野道郎編『秩序問題と社会的ジレンマ』ハーベス

卜社, 167-97.

Leach, E., 1976, Culture and Communication, Cambridge: Cambridge University Press. (=1981，青 木保・宮坂敬造訳『文化とコミュニケーション』紀伊国屋書店.)

宮本光晴，1983，「『集合行為論』『季刊現代経済』55：155-9.

森脇俊雅, 2000, 『集団·組織』東京大学出版会.

牟田和恵, 1986,「運動の形成と資源動員論」『ソシオロジ』30(3): 57-76.

丹辺宣彦, 2001, 「階層的集団形成と物象性—M. Douglasにおける『けがれ』と象徵作用をめぐ って」『名古屋大学社会学論集』22: 99-113.

Oberschall, A., 1978, “Theories of Social Conflict,” Annual Review of Sociology, 4: 291-315. (=1989, 鵜飼孝造訳「崩壊理論加連帯理論へ」塩原勉編『資源動員と組織戦略』新曜社, 59-91.)

Offe, C., 1985, Disorganized Capitalism, Cambridge, M. A.: The MIT Press.

Olson, M., 1965, The Logic of Collective Action, Cambridge, M. A.: Harvard University Press. (=1983, 依田博・森脇敏雅訳『集合行為論』ミネルヴァ書房.)

Ostrom, E., 1990, Governing the Commons: The Evolution of Institutions for Collective Action, Cambridge: Cambridge University Press.

Roemer, J., 1978, "Neoclassicism, Marxism, and Collective Action," Journal of Economic Issues, 7 (1): 147-61.

Smith, Jan, 1976, "Communities, Associations, and the Supply of Collective Goods," American Journal of Sociology, 82(2): 291-308.

Taylor, M., 1982, Community, Anarchy \& Liberty, Cambridge: Cambridge University Press.

Tilly, C., 1978, From Mobilization to Revolution, New York: McGraw-Hill.（=1984，小林良彰·佐 治孝夫・桜内篤子訳『政治変動論』芦書房.)

（名古屋大学助教授, 146750a@nucc.cc.Nagoya-u.ac.jp)

（原稿受付 2001.11.24 揭載決定 2003.2.18) 


\title{
Collective Action, Group Formation and Class/Strata: Reification and Symbolism around Group Category
}

\author{
Nobuhiko NIBE \\ Nagoya University \\ 146750a@nucc.cc.Nagoya-u.ac.jp
}

Collective action theory has demonstrated an irrefutable effectiveness in rebutting the main thesis of class theory that those who share common interests tend to act collectively as a class. On the other hand, it overlooks the point that stratified group formation affects and changes its members' consciousness and behavior to a great extent. From this perspective of sociology, this paper tries to explicate the significance of "reification-symbolization" phenomenon seen in group category formation, which in turn binds and canalizes class members' collective action and the subsequent group formation.

With this in mind, I will argue, first, that Olson's free-rider can be a free-rider only when he/she is automatically counted as a beneficiary on the ground that he/she has the attributes of a group member. Next, the class-relevance of the collective good/bad will be explored and the "reification" problem examined in relation to the "collective identity" problem posed by C. Offe. Thirdly, the imaginary identification of a member with the group as a whole is accomplished through reified group category formation, although this identification will break down just as frontrunners begin to contribute to the collective good.

Key words: collective action, stratification, reification

(Received November 24, 2001/Accepted February 18, 2003) 